\title{
Upaya Peningkatan Status Kesehatan Kelompok Rentan dengan Pendekatan Pembelajaran dan Pemberdayaan Masyarakat
}

\author{
Cahyo Wulandari ${ }^{1 *}$, Dwi Wahyu Setiyarini², Khulatul Bariroh² Laraswati $^{3}$, M. Fa'iq Azhari ${ }^{4}$, \\ Rezza Abdurrahman Ibnu Aziz ${ }^{5}$ \\ ${ }^{1}$ Fakultas Pertanian Universitas Gadjah Mada, JL. Flora, Bulaksumur, Karang Malang, Caturtunggal, \\ Depok, Sleman, Daerah Istimewa Yogyakarta 55281. \\ ${ }^{2}$ Fakultas Kedokteran, Universitas Gadjah Mada, Jl. Farmako, Senolowo, Sekip Utara, Depok, Sleman, \\ Daerah Istimewa Yogyakarta 55281. \\ ${ }^{3}$ Fakultas Farmasi, Universitas Gadjah Mada, Jalan Sekip Utara, Senolowo, Sinduadi, Mlati, Sleman, \\ Daerah Istimewa Yogyakarta 55281. \\ ${ }^{4}$ Fakultas Kedokteran Gigi, Universitas Gadjah Mada, Jl.Denta 1, Sekip Utara, Yogyakarta 55281. \\ ${ }^{5}$ Fakultas Matematika dan Ilmu Pengetahuan Alam, Universitas Gadjah Mada, Sekip Utara Bulaksumur, \\ Kotak Pos 21, Senolowo, Sinduadi, Mlati, Sleman, Daerah Istimewa Yogyakarta 55281.

\section{* cahyowulandari.cw@gmail.com}

Submisi: 21 Desember 2018; Penerimaan: 05 April 2019

\begin{abstract}
Kata Yunci: kelompok rentan; pemberdayaan masyarakat; peningkatan status kesehatan.

Abstrak Kelompok rentan adalah suatu kelompok yang idealnya diperhatikan oleh pemerintah dan berbagai pihak. Hal ini tercantum dalam UU No. 39 tahun 1999 tentang kelompok rentan. Penerapan undang-undang tersebut sangat penting dilakukan oleh semua pihak termasuk akademisi. Artikel ini menjelaskan tentang program pengabdian masyarakat khususnya pada kesehatan kelompok rentan di kegiatan KKN-PPM (Kuliah Kerja Nyata-Pengabdian Pemberdayaan Masyakat) tahun 2017 di Desa Kebonrejo, Kecamatan Banjarejo, Blora. Metode yang digunakan adalah sensus, wawancara, pendekatan yang observatif dan studi dokumentasi. Analisis yang dilakukan berfokus pada hal pengolahan data angka yang diinterpretasikan dengan fenomena kesehatan pada masyarakat desa tersebut. Analisis tersebut menghasilkan penyelesaian masalah berupa konsultasi, pendidikan dan pelatihan dalam bidang kesehatan. Beberapa program yang tim lakukan adalah sensus kesehatan, pelatihan kader kesehatan, pendampingan posyandu, penyuluhan swamedikasi dan pemeriksaan kesehatan lanjut usia. Dengan metode penyelesaian masalah tersebut diharapkan dapat turut membantu menyelesaikan masalah kesehatan kelompok rentan di Desa Kebonrejo. Selain hal itu, artikel ini juga menjelaskan pentingnya ada kader atau kelompok masyarakat yang terjun langsung dalam bidang kesehatan dan mengevaluasi kegiatan kelompok tersebut.
\end{abstract}

Teywords: $\quad$ Abstract Vulnerable group is a group that ideally noticed by the government and community other people. This statement listed by UU No. 39 tahun 1999 about vulnerable empowerment; $\quad$ group. The implementation of that regulation is very important done by all people health status include academic. This article describes the programs of community service improvement; vulnerable group. especially on vulnerable group's health in KKN-PPM (Kuliah Kerja NyataPengabdian Pemberdayaan Masyakat) year 2017 in Kebonrejo Village, Banjarejo, Blora. The method use census, interview, observation and documentary study. The 
analysis focused on analyzing numeric data which is interpreted with health phenomena in that village. The analysis give problem solving in the form of consultation, education and health training. Some of the programs that team did were health census, health cadre training, posyandu guidance, swamedikasi education and elderly health examination. With that method, we expect to solve the health problems of vulnerable groups in Kebonrejo village. In addition, this article also explains the importance of existing cadres or community group who are directly involved in health and evaluating the group activity.

\section{PENDAHULUAN}

Desa Kebonrejo merupakan salah satu desa di Kabupaten Blora dari jumlah total desa sebanyak 271 desa. Desa Kebonrejo terdiri dari tiga dusun yakni Dusun Pruntusan, Dusun Kebonrejo dan Dusun Nglempung. Desa Kebonrejo memiliki kondisi fisik dan sumber daya alam yang mendukung kegiatan di bidang pertanian dan peternakan. Kelompok rentan yang dijelaskan pada UU No. 39 tahun 1999, yaitu orang lanjut usia, anak-anak, fakir miskin, wanita hamil dan penyandang cacat. Undang-undang tersebut menyatakan bahwa setiap orang yang termasuk dalam kelompok masyarakat yang rentan berhak memperoleh perlakuan dan perlindungan lebih berkenaan dengan kekhususannya (Hoesin, 2004). Populasi kelompok rentan di Indonesia cukup tinggi, tetapi tidak beriringan dengan banyaknya peraturan perundang-undangan tentang kelompok rentan yang implementasinya sangat beragam.

Balita, ibu hamil, dan lansia (lanjut usia) adalah 3 kelompok rentan yang banyak terdapat di masyarakat. Balita merupakan salah satu kelompok rentan yang harus paling diperhatikan. Keberhasilan pengontrolan pada saat balita akan berdampak pada masa yang akan datang. Masa pertumbuhan tercepat seorang anak adalah 1000 hari pertama kehidupan (1000 HPK) (Afifa dkk, 2016). Setiap tiga menit di manapun di Indonesia, satu balita meninggal dunia (UNICEF, 2012). Angka tersebut sangat mengejutkan. Berdasarkan data Riskesdas 2010, sebanyak 50\% balita di Indonesia tidak 
melakukan penimbangan teratur di posyandu. Riset ini sekaligus menunjukkan kecenderungan semakin bertambah umur seorang balita, maka tingkat kunjungan ke posyandu untuk melakukan penimbangan rutin semakin menurun. Ketika anak berusia enam bulan, jumlah kunjungan masih cukup tinggi yakni sekitar $68 \%$, tetapi posyandu rata-rata ditinggalkan saat usia anak tiga tahun ke atas. Hal ini cukup disayangkan, karena menurut penelitian Anwar dkk (2010), aktivitas mengunjungi posyandu dapat memberi dampak positif bagi status kesehatan balita. Kondisi ini salah satunya dipengaruhi oleh cara pandang orangtua yang merasa anaknya tidak perlu lagi dibawa ke posyandu seiring dengan pertambahan umur. Selain itu, minimnya kepercayaan para orang tua terhadap kinerja kader posyandu juga berkorelasi positif terhadap jumlah kunjungan balita ke posyandu.

Masalah tidak berhenti dari jumlah partisipasi, balita juga memiliki masalah yang cukup serius yaitu indeks masa tubuh (IMT) kurang dari angka normal yaitu 17. Keadaan IMT tersebut tentu tidak hadir begitu saja. Masalah balita pendek menggambarkan adanya masalah gizi kronis salah satunya dipengaruhi dari kondisi ibu/calon ibu dan masa janin. Sebagian besar kematian anak di Indonesia saat ini terjadi pada masa baru lahir (neonatal). Oleh karena itu, ibu hamil adalah salah satu kelompok rentan yang harus diperhatikan. Selain ibu hamil, kelompok lansia merupakan kelompok yang juga patut diperhatikan kesehatannya. Lansia dikategorikan sebagai kelompok rentan karena biasanya kelompok lansia lebih mudah terserang beberapa jenis penyakit. Penuaan sel dalam tubuh lansia menyebabkan penurunan daya tahan tubuh sehingga mudah diserang virus dan bakteri penyakit. Merujuk peningkatan status kesehatan kelompok rentan, tim Kuliah Kerja Nyata Pengabdian Pembelajaran Masyarakat Universitas Gadjah Mada (KKN-PPM UGM) JTG-19 tahun 2017 melakukan beberapa 
program. Informasi dan data yang dibutuhkan dalam program diambil dari hasil analisis sensus potensi Desa Kebonrejo pada tahun 2016 dan 2017. Selain itu, sumber lain seperti data posyandu dan wawancara dengan kader kesehatan juga menjadi pertimbangan dalam pelaksanaan program. Adapun informasi yang didapatkan kemudian didiskusikan oleh tim untuk pengambilan keputusan terkait program.

Beberapa program yang sudah dilakukan untuk mencoba menangani permasalahan pada kelompok rentan adalah program KKN sebelumnya yang lebih fokus pada posyandu dan kader. Program posyandu dari desa juga berfokus pada balita. Penggunaan Dana Desa (DD) tahun anggaran 2017 wajib dialokasikan untuk pemberikan makan tambahan untuk balita dan anak sekolah, serta perawatan kesehatan ibu hamil dan menyusui. Ketentuan tersebut diatur dalam Peraturan Pemerintah (PP) No.22 tahun 2016 tentang Penetapan Prioritas Penggunaan Dana Desa (DD) tahun 2017 dalam hal kegiatan prioritas bidang pemberdayaan masyarakat desa.

Kegiatan ini dilaksanakan di Desa Kebonrejo, Kecamatan Banjarejo, Kabupaten Blora. Eksekusi utama kegiatan dilaksanakan mulai tanggal 10 Juni 2017 hingga 4 Agustus 2017 selama 8 minggu efektif. Sementara monitoring berjalan hingga November 2017 dengan waktu yang fleksibel menyesuaikan kebutuhan. Tujuan dari kegiatan ini adalah untuk meningkatkan kesehatan kelompok rentan dengan meningkatkan kesadaran tentang kesehatan pada masyarakat pada umumnya dan kelompok rentan pada khususnya, menggali data-data terkait kelompok rentan lewat sensus kesehatan, meningkatkan fungsi posyandu, serta memeriksa kesehatan lansia.

\section{MASALAH}

Desa Kebonrejo memiliki potensi yang sangat besar pada bidang pertanian dan 
peternakan. Berdasarkan data BPS 2013, Kabupaten Blora memiliki populasi ternak sapi terbanyak di Jawa Tengah yang sebagian berada di Desa Kebonrejo. Mayoritas masyarakat bermatapencaharian sebagai peternak dan petani. Dibalik potensi yang besar, tersembunyi pula beberapa masalah di dalamnya. Pengelolaan ternak di desa masih menggunakan metode tradisional sehingga manajemen pemeliharan kesehatannya belum memadai baik bagi ternak maupun manusianya. Hal ini tercermin dari penempatan kandang ternak terutama sapi masih tidak berbatas jelas dengan hunian manusia, seperti penempatan sapi atau kandang sapi yang terlalu dekat dengan dapur, kamar mandi, dan bahkan tempat tidur.

Permasalahan yang ada di desa ini juga terkait dengan sumber daya manusianya. Hal ini terkait dengan kelompok rentan yang terdiri dari balita, lansia, dan ibu hamil. Populasi balita di Desa Kebonrejo terdapat sekitar 7\% dari populasi total penduduk. Populasi lansia di Desa Kebonrejo sekitar 17\% dari total penduduk. Dengan demikian, hampir seperempat dari populasi masyarakat Desa Kebonrejo adalah kelompok rentan. Hal ini membawa permasalahan tersendiri terutama status kesehatan masyarakat Desa Kebonrejo. Pada umumnya, lansia Desa Kebonrejo menderita berbagai macam penyakit, baik menular maupun tidak menular. Sel-sel pada tubuh lansia mengalami penuaan sehingga mudah untuk terserang virus, bakteri, ataupun lainnya. Lansia membutuhkan perhatian khusus berupa pengontrolan kesehatan secara berkala baik fisik maupun psikis. Pemerintah desa dapat memanfaatkan bantuan dari kader kesehatan untuk melakukan pengontrolan kesehatan tersebut.

Tidak semua balita di Desa Kebonrejo melakukan kunjungan Posyandu setiap bulannya. Tingkat kesadaran orangtua untuk mengontrol tumbuh kembang anak masih rendah. Berdasarkan data dari posyandu, jumlah balita yang berkunjung ke Posyandu 
kurang dari 50\% populasi balita Desa Kebonrejo. Bidan desa dan kader kesehatan diharapkan dapat memberikan pendidikan kesehatan dan mengajak orangtua beserta balitanya untuk ke berkunjung ke Posyandu secara berkala. Pemerintah desa juga dapat memperbaiki sistem Posyandu yang telah ada sehingga dapat memaksimalkan fungsinya. Balita dengan IMT $<17$ (Indeks Masa Tubuh kurang dari 17) menandakan bahwa balita tersebut memiliki angka kecukupan gizi yang kurang baik. Angka kecukupan gizi dapat memengaruhi tumbuh kembang serta kecerdasan balita sehingga apabila angka kecukupan gizi baik, maka dapat mendukung proses tumbuh kembangnya. Balita dengan IMT $<17$ membutuhkan perhatian khusus terkait dengan makanan yang dikonsumsi, baik jenis makanannya maupun gizi yang dikandungnya. Pemerintah desa dapat bekerjasama dengan kader kesehatan untuk melakukan pemberian makanan tambahan serta pemantauan berat badan secara berkala.

Kesehatan ibu hamil juga perlu diperhatikan karena kesehatan dan kecukupan gizi diperlukan untuk menunjang tumbuh kembang janin. Untuk menghasilkan bangsa yang sehat dan cerdas, dimulai dari janin yang sehat serta balita yang kuat. Oleh karena itu, pemerintah beserta tenaga kesehatan yang ada berkewajiban memberikan edukasi serta pendampingan terhadap ibu hamil terkait dengan kesehatannya. Pelayanan kesehatan yang minim juga menjadi persoalan. Hanya terdapat 1 bidan desa yang mengampu kesehatan sekitar 2300-an jiwa di Desa Kebonrejo. Apabila warga mengalami gangguan kesehatan biasanya warga memeriksakan dirinya ke bidan desa. Meskipun terdapat fasilitas kesehatan tingkat pertama yaitu puskesmas, masyarakat desa banyak yang enggan memeriksakan diri ke puskesmas dengan alasan tidak cocok, serta tidak sedikit yang beralih untuk memeriksakan diri ke dokter swasta. Dengan berbagai permasalahan yang ada, tim berupaya untuk menjadi sebuah solusi dengan 
melakukan kegiatan-kegiatan pembelajaran dan pemberdayaan masyarakat yang bertujuan guna meningkatkan status kesehatan kelompok rentan di Desa Kebonrejo.

\section{METODE}

Pada kegiatan ini, tim menggunakan beberapa jenis metode untuk menyelesaikan masalah, yaitu sensus kesehatan, pelatihan, konsultasi, dan pendidikan masyarakat. Pada awal kegiatan, tim turun langsung ke dalam masyarakat untuk melihat kondisi dan masalah yang ada. Sensus dilakukan dengan cara membagi tim menjadi kelompok kecil untuk mengunjungi rumah warga satu per satu dan melakukan wawancara. Prioritas dari sensus ini adalah untuk mendapatkan informasi kesehatan masyarakat, terutama kelompok rentan. Hasil dari sensus ini dipergunakan sebagai data pendukung program selanjutnya dan menjadi bahan pertimbangan pemerintah desa untuk menentukan kebijakan terkait dengan kesehatan masyarakatnya.

Selanjutnya adalah pelatihan kader kesehatan yang merupakan program untuk meningkatkan pengetahuan serta keterampilan para kader. Program ini bertujuan agar peran kader kesehatan dalam meningkatkan status kesehatan masyarakat dapat optimal. Dalam hal ini, peran kader tidak hanya berfokus pada kesehatan pribadi ataupun keluarga, akan tetapi bisa berpengaruh terhadap masyarakat luas, serta tugas dan fungsinya dapat dilaksanakan secara maksimal. Setelah dilaksanakannya pelatihan untuk kader kesehatan Desa Kebonrejo Kabupaten Blora, diharapkan para kader dapat berkerja dan berperan dalam pelayanan dan pembangunan kesehatan masyarakat sehinga dapat meningkatkan kualitas hidup masyarakat, terutama kelompok rentan.

Metode berikutnya adalah konsultasi. Konsultasi merupakan program yang digunakan untuk kegiatan-kegiatan yang di dalamnya persoalan diselesaikan melalui 
sinergisme dengan Perguruan Tinggi. Dalam hal ini, permasalahan yang didapatkan melalui sensus kesehatan berusaha dipecahkan melalui ilmu yang telah didapatkan di perguruan tinggi, melalui program pendampingan posyandu dan pemeriksaan kesehatan. Pendampingan posyandu dilakukan dengan tujuan agar program posyandu Desa Kebonrejo Kabupaten Blora dapat terlaksana secara efektif dan efisien, dan tidak terfokus pada balita saja, namun juga ibu hamil dan lansia. Pemeriksaan kesehatan disini dilakukan dengan mengecek kesehatan masyarakat Desa Kebonrejo secara umum.

Metode terakhir adalah pendidikan masyarakat. Sebagian masyarakat masih menggunakan pengobatan atau terapi yang tidak sesuai dengan evidence based medis. Terkadang juga mempercayai mitos-mitos yang berkembang di masyarakat. Hal ini dapat berbahaya bagi kesehatan masyarakat itu sendiri. Selain itu, obat-obat yang mudah dibeli masyarakat seperti di warung perlu pengetahuan untuk penggunaan yang tepat dan mencegah penyalahgunaan. Dari masalah tersebut perlu dilakukan penyuluhan swamedikasi kepada kelompok rentan di Desa Kebonrejo. Swamedikasi adalah upaya masyarakat melakukan pengobatan sendiri secara tepat untuk penyakit ringan tanpa berobat ke dokter. Materi disampaikan oleh mahasiswa menggunakan power point dan diskusi interaktif dengan masyarakat. Pendidikan kesehatan ini dilakukan bersamaan dengan acara warga sehingga cakupan warga yang datang cukup luas.

\section{HASIL DAN PEMBAHASAN}

Hasil dan pembahasan penelitian didapatkan dengan metode sensus kesehatan, pelatihan, konsultasi, dan pendidikan masyarakat.

\subsection{Pemberdayaan Berbasis Sensus Kesehatan}


Sensus kesehatan dilaksanakan satu kali di awal kegiatan KKN pada bulan Juni 2017 untuk mengetahui jumlah dan masalah yang ada pada kelompok rentan. Data yang telah terkumpul kemudian diolah menggunakan analisis data eksploratif (Ade, 2011). Berdasarkan hasil sensus kesehatan, Desa Kebonrejo, Kecamatan Banjarejo, Blora memiliki 164 balita, 12 ibu hamil dan 390 lansia (Gambar 1). Jika dibandingkan dengan populasi keseluruhan, 24,7\% dari warga adalah kelompok rentan pada tiga (3) kategori tersebut. Masing-masing dusun memiliki jumlah kelompok rentan yang berbeda namun secara garis besar Dusun Kebonrejo memiliki jumlah kelompok rentan yang paling banyak. Salah satu faktornya karena wilayah yang paling luas. Berikut diagram populasi kelompok rentan.

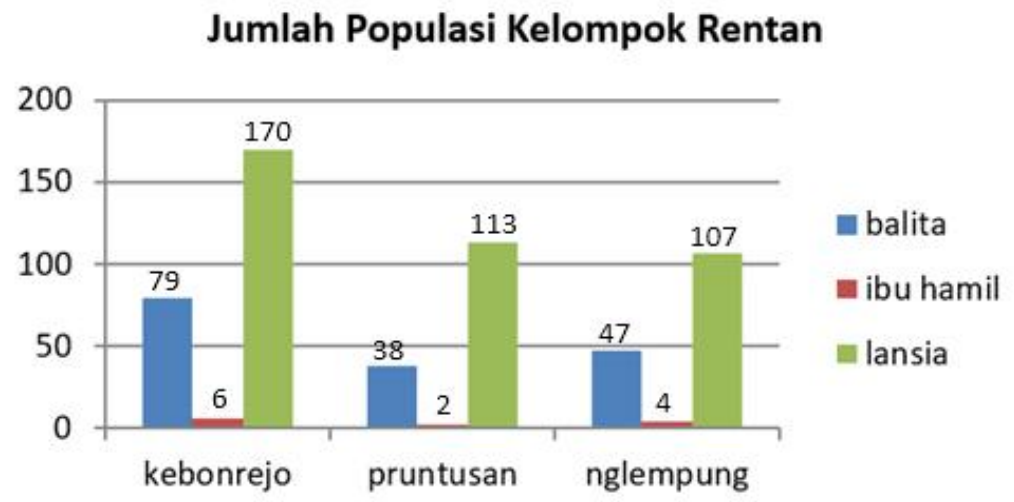

Sumber: Data primer diolah (2017)

Gambar 1. Diagram jumlah populasi kelompok rentan

Cakupan yang dimiliki posyandu menjadi penting untuk terus memantau pertumbuhan dan perkembangan balita. Berdasarkan hasil sensus hanya 80 dari 164 balita Kebonrejo yang datang ke posyandu pada Juni 2017. Angka tersebut sangat rendah karena kurang dari setengah total populasi balita yang datang ke posyandu. Lebih memprihatinkannya lagi, dari 80 balita yang datang ke posyandu, 71 balita memiliki indeks masa tubuh (IMT) di bawah 17 (Gambar 2). 


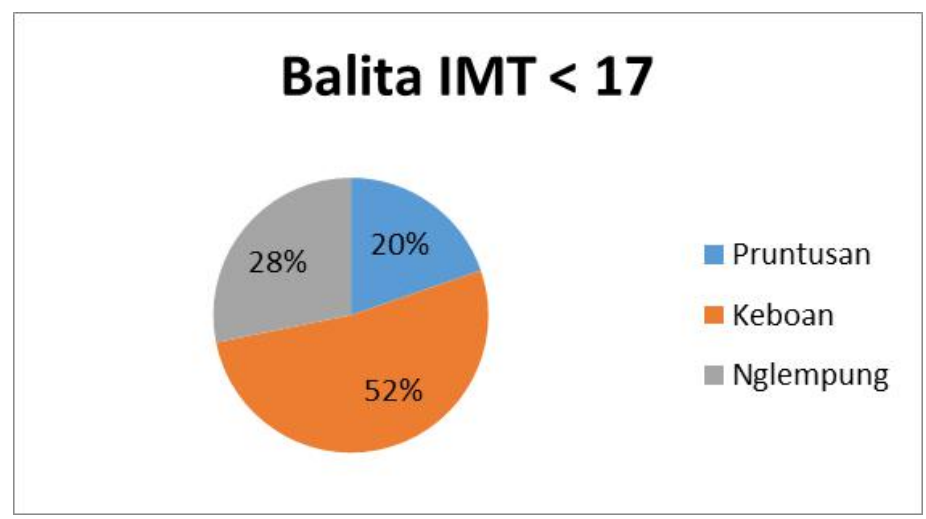

Sumber: Data primer diolah (2017)

Gambar 2. Diagram persebaran balita dengan IMT $<17$ di Desa Kebonrejo

Indeks masa tubuh (IMT) digunakan untuk mengukur status gizi seseorang, apakah tergolong kurus, normal atau berlebih. IMT $<17$ pada balita berarti balita tersebut mengalami kekurangan gizi. Potensi tinggi badan seorang anak sangat bergantung pada kecukupan gizi yang didapat selama masa ini. Status gizi balita pendek (stunting) di Indonesia belum menunjukan perbaikan tiap tahunnya yaitu $36,8 \%$ pada 2007, 35,6\% pada 2010 dan 37,2\% pada 2013 (Pusat Data dan Informasi Kemenkes RI, 2016).

Dari hasil analisis data, 4 dari 12 ibu hamil yang ada di Desa Kebonrejo merupakan ibu dengan kehamilan berisiko ditinjau dari umur, lingkar lengan atas dan kurang energi kronis (KEK) yang dilihat dari IMT. Rendahnya awareness terhadap hal ini juga menjadi masalah tersendiri karena ibu hamil dan keluarga di sana cenderung kurang peduli terhadap kehamilannya.

Berdasarkan sensus yang dilakukan pada bulan Juni 2017, didapatkan jumlah lansia Desa Kebonrejo yaitu 390 jiwa dengan data sebaran jenis penyakit (Gambar 3). 


\section{Penyakit/keluhan pada Lansia}

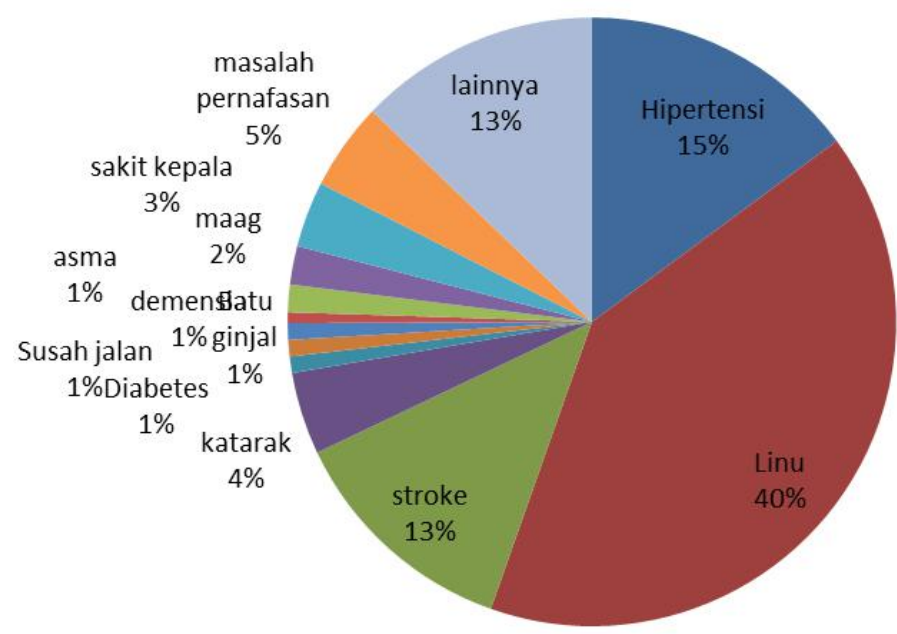

Sumber: Data primer diolah (2017)

Gambar 3. Presentase persebaran penyakit pada lansia Desa Kebonrejo

Lansia Desa Kebonrejo terbanyak mengeluhkan linu-linu sejumlah 40\% (135 jiwa). Linu merupakan tanda dan gejala suatu penyakit, sehingga membutuhkan pemeriksaan lebih lanjut untuk mendiagnosis jenis penyakitnya. Hipertensi menempati peringkat kedua setelah linu. Sejumlah 15\% (51 jiwa) memiliki tekanan darah di atas angka normal. Penyakit tidak menular selanjutnya yaitu stroke sejumlah 13\% (43 jiwa).

\subsection{Pembelajaran Melalui Pelatihan Kader Kesehatan}

Kader kesehatan memiliki peran penting dalam menyokong kesehatan masyarakat Desa Kebonrejo. Idealnya, seorang kader kesehatan memiliki pengetahuan tentang kesehatan lebih dalam dibandingkan masyakarat secara umum. Selain pengetahuan, kesadaran dan motivasi untuk menjaga kesehatan yang dimiliki seorang kader kesehatan seharusnya tidak sebatas menjaga kesehatan diri sendiri, akan tetapi juga berkontribusi positif dalam menjaga kesehatan masyarakat lingkungan sekitar dalam bentuk promotif dan 
preventif. Ketiga hal ini akan sangat berpengaruh terhadap keaktifan para kader menjaga kesehatan masyarakat (Wijaya dkk, 2013).

Kondisi ideal ini masih belum ditemui dalam diri kader kesehatan Desa Kebonrejo. Kader Kesehatan disini difungsikan hanya sebagai penyelenggara posyandu, belum pada tahap selanjutnya yaitu mulai mempromosikan kesehatan kepada masyarakat umum dan juga fungsi lainnya seperti konselor sebaya dan pembinaan remaja. Pelaksanaan posyandu pun dirasa kurang memenuhi standar dimana banyak ditemukan cara pengukuran antropometri bayi dan balita yang kurang akurat, tidak teratur dan banyak fasilitas alat kesehatan yang masih belum dapat digunakan dengan baik. Kondisi kader kesehatan Dusun Pruntusan yang masih baru juga butuh untuk dilatih. Oleh karena itu, pelatihan kader kesehatan perlu untuk diadakan.

Mengacu pada target dan luaran pelatihan kader kesehatan oleh WHO (1995) dan pada penelitian Negara dkk (2016), pelatihan kader kesehatan dilaksanakan sebanyak 2 kali, yaitu pada tanggal 10-11 Juli 2017 dan 27 Juli 2017. Serta pelatihan susulan pada 31 Juli 2017. Pada pelaksanaan pertama, pelatihan diisi langsung oleh dosen PSIK FK UGM, dengan materi pelaksanaan posyandu yang baik, nutrisi anak dan pengenalan dan cara pemakaian alat kesehatan. Setelah pelatihan kader kesehatan yang pertama ini, tim secara langsung melakukan tindak lanjut dengan cara ikut menerjunkan kader kesehatan pada program pendampingan posyandu terutama saat pemberian makanan tambahan dan FGD (Forum Group Discussion) dengan ibu balita. Pelatihan kader kesehatan yang kedua dan pelatihan susulan dimaksimalkan untuk pelatihan alat kesehatan. Hal ini bertujuan agar kader yang ada dapat memanfaatkan fasilitas yang telah ada di masing-masing posyandu. Setelah pelatihan kader kesehatan yang kedua ini, 
segera dilakukan follow up dengan cara ikut menerjunkan kader kesehatan pada saat program pemeriksaan kesehatan.

Tantangan yang tim hadapi adalah komunikasi dan koordinasi. Terjadinya perubahan timeline membuat hari pelatihan pertama cukup kacau dimana mahasiswa KKN sedang melakukan program lain di tempat yang sama. Hal ini bisa diantisipasi dengan memindah tempat pelaksanaan dari Balai Desa Kebonrejo ke SD Kebonrejo 2.

\subsection{Pemberdayaan Pendampingan Posyandu}

Posyandu merupakan salah satu bentuk Upaya Kesehatan Bersumberdaya Masyarakat (UKBM) yang dikelola oleh, dari, untuk, dan bersama masyarakat, guna memberdayakan masyarakat dan memberikan kemudahan kepada masyarakat dalam memperoleh pelayanan kesehatan dasar (Kemenkes, 2012). Desa Kebonrejo, Banjarejo, Blora memiliki empat Posyandu yang tersebar di tiga dusun, yaitu Dusun Pruntusan, Kebonrejo, dan Nglempung. Sesuai dengan standar Posyandu, pelaksanaan ke-empat Posyandu tersebut dibantu oleh kader kesehatan (memberdayakan masyarakat). Posyandu tersebut dilaksanakan setiap bulan sekali yang didampingi oleh bidan desa.

Posyandu Dusun Pruntusan diselenggarakan di Balai Desa yang dibantu oleh lima kader kesehatan. Kader tersebut membantu dalam penimbangan berat badan balita, pengukuran tinggi badan balita, serta melakukan pendokumentasian. Sedangkan Posyandu Dusun Kebonrejo diselenggarakan di dua tempat dengan hari yang berbeda. Penyelenggaraan dua kali Posyandu dikarenakan wilayah Dusun Kebonrejo yang luas, apabila diselenggarakan hanya di satu tempat maka kurang efektif. Meskipun penyelenggaraan dua kali, Dusun Kebonrejo memiliki kader kesehatan yang paling sedikit, hal ini menjadi salah satu penyebab kurang efektifnya kegiatan Posyandu. 
Dusun Nglempung memiliki lima kader kesehatan yang membantu pelaksanaan kegiatan Posyandu.

Pendampingan Posyandu oleh tim dilakukan dua kali yaitu pada bulan Juni dan Juli 2017. Tim mendampingi selama proses pelaksanaan serta melakukan evaluasi terhadap jalannya Posyandu. Tim melakukan demonstrasi kepada kader kesehatan terkait dengan pelaksanaan Posyandu sistem lima meja. Kegiatan pendampingan Posyandu lainnya yaitu edukasi kelompok sebaya atau peer education. Kegiatan ini mengacu pada penelitian yang dilakukan oleh Aisah dkk (2010) yang dapat mengubah perilaku masyarakat menjadi lebih sehat. Kegiatan tersebut merupakan upaya untuk mencegah dan mengurangi gangguan secara langsung (intervensi gizi spesifik) dan upaya untuk mencegah dan mengurangi gangguan secara tidak langsung (intervensi gizi sensitif). Sasaran kegiatan peer education meliputi balita, lansia, dan ibu hamil. Pada kelompok balita, tim mengadakan kegiatan pemberian makanan tambahan kepada balita dengan IMT $<17$. Pemberian makanan tambahan ini diselingi dengan penyuluhan berbentuk forum group discussion.

Hasil program tersebut tentunya tidak bisa dilihat secara langsung. Penambahan berat badan pada bulan selanjutnya terlihat meningkat pada sebagian besar balita. Namun perlu terus dikontrol pada bulan-bulan selanjutnya. Hasil yang bisa dilihat langsung adalah adanya partisipasi lebih dari ibu balita dan kader kesehatan. Karena dari program ini, kader kesehatan dituntut untuk bisa menyediakan makanan yang baik bagi balita, memimpin diskusi dan memantik partisipasi ibu. Program peer education ini bisa dilanjutkan dengan partisipasi kader dan ibu balita serta tentunya adanya dukungan pemerintah Blora untuk melakukan kontrol alokasi dana desa untuk makanan tambahan Balita. Penggunaan Dana Desa (DD) tahun anggaran 2017 wajib mengalokasikan dana 
untuk memberikan makan tambahan untuk Balita, anak sekolah dan perawatan kesehatan ibu hamil dan menyusui. Ketentuan tersebut diatur dalam Peraturan Pemerintah (PP) No.22 tahun 2016 tentang Penetapan Prioritas Penggunaan Dana Desa (DD) tahun 2017 dalam hal kegiatan prioritas bidang pemberdayaan masyarakat desa.

Intervensi gizi spesifik tidak akan berjalan baik tanpa intervensi gizi sensitif. Intervensi gizi spesifik seperti peer education hanya berkontribusi $30 \%$, sedangkan $70 \%$ nya merupakan kontribusi intervensi gizi sensitif yang melibatkan berbagai sektor seperti ketahanan pangan, ketersediaan air bersih dan sanitasi, penanggulangan kemiskinan, pendidikan, sosial, dan sebagainya. Pemerintah kabupaten Blora khususnya memiliki peran yang sangat penting bagi tercapainya 70\% kontribusi gizi sensitif yaitu lewat beberapa pihak contohnya Dinas Kesehatan, Dinas Pendidikan dan Dinas Sosial. Langkah strategis yang bisa diambil adalah dengan penurunan Dana Desa yang sesuai dan dengan dana Bantuan Operasional Kesehatan untuk pemberian makanan tambahan pemulihan bagi balita gizi kurang lewat Dinas Kesehatan Blora ke Ditjen Bina Gizi dan Kesehatan Ibu dan anak Kementrian Kesehatan RI.

Dampak buruk yang dapat ditimbulkan oleh masalah gizi pada periode balita, dalam jangka pendek adalah terganggunya perkembangan otak, kecerdasan, gangguan pertumbuhan fisik, dan gangguan metabolisme dalam tubuh. Sedangkan dalam jangka panjang akibat buruk yang dapat ditimbulkan adalah menurunnya kemampuan kognitif dan prestasi belajar, menurunnya kekebalan tubuh sehingga mudah sakit, dan risiko tinggi untuk munculnya penyakit diabetes, kegemukan, penyakit jantung dan pembuluh darah, kanker, stroke, dan disabilitas pada usia tua, serta kualitas kerja yang tidak kompetitif yang berakibat pada rendahnya produktivitas ekonomi. 
Pelaksanaan peer education pada kelompok lansia berupa pemeriksaan kesehatan yang meliputi pengecekan kadar asam urat, dan kolesterol, serta konseling kesehatan. Menurut World Health Organization (WHO), lansia merupakan seseorang yang telah memasuki usia 60 tahun ke atas. Fungsi organ tubuh manusia akan menurun sebanyak satu persen setiap tahunnya setelah usia 30 tahun, oleh karena itu perlu dilakukan pemantauan kesehatan secara rutin. Proses menua setiap individu dan setiap organ tubuh berbeda, hal ini dipengaruhi oleh gaya hidup, lingkungan dan penyakit degenerative. Proses menua dan perubahan fisiologis pada lansia mengakibatkan beberapa kemunduran dan kelemahan, serta implikasi klinik berupa penyakit kronik dan infeksi. Beberapa kondisi lansia yang mengalami penurunan fungsi seperti berkurangnya fungsi paru, menurunnya sistem imun, serta meningkatnya resiko penurunan fungsi sendi dan tulang (pengeroposan). Penyuluhan kesehatan yang dilakukan oleh tim berupa pengetahuan tentang pola hidup sehat yang bertujuan untuk membantu mengontrol penyakit serta mencegah timbulnya berbagai penyakit. Selain itu, lansia dianjurkan untuk berolahraga secara teratur untuk meningkatkan dan mempertahankan kebugaran dan kesehatan.

Program peer education juga diselenggarakan pada kelompok ibu hamil. Dalam pelaksanaannya, tim bekerjasama dengan bidan desa menyelenggarakan kelas ibu hamil. Kelas ibu hamil ini diikuti oleh seluruh ibu hamil di Desa Kebonrejo, dan diselenggarakan di Balai Desa pada tanggal 14 Juli 2017. Kelas ibu hamil ini berisi penyampaian materi serta diskusi terkait dengan pola hidup sehat ibu hamil serta tanda bahayanya.

\section{4. $\quad$ Pemberdayaan Melalui Penyuluhan Swamedikasi}


Penyuluhan kesehatan merupakan salah satu program yang tidak bisa lepas dari kegiatan pengabdian masyarakat. Penyuluhan kesehatan merupakan salah satu upaya promotif untuk meningkatkan derajat kesehatan masyarakat. Penyuluhan kesehatan yang juga dilakukan di Desa Kebonrejo adalah penyuluhan swamedikasi. Swamedikasi atau pengobatan sendiri adalah usaha seseorang untuk mengobati sendiri penyakitnya tanpa ke dokter terlebih dahulu. Menurut data Riskesdas pada tahun 2010, sekitar 55,8\% masyarakat Indonesia melakukan pengobatan sendiri jika mengalami sakit. Namun, banyak sekali masyarakat yang melakukan pengobatan sendiri cenderung sembarangan menggunakan obat karena ketidaktahuan atau ketidakpedulian terhadap kesehatan diri. Dalam hal ini, penyuluhan swamedikasi dilaksanakan di desa karena melihat data yang menunjukkan banyak masyarakat yang melakukan pengobatan sendiri untuk meringankan gejala yang dirasakan dan kecenderungan masyarakat yang jarang memeriksakan kesehatannya ke dokter.

Penyuluhan ini dilakukan bersama dengan program keluarga harapan (PKH) Desa Kebonrejo pada tanggal 23 Juli 2017 di Balai Desa. Penyuluhan ini dihadiri oleh 116 orang. Peserta mendapatkan materi berupa materi pengobatan sendiri, pengenalan jenis-jenis obat-obatan, dan cara mendapatkan, menggunakan, menyimpan, serta membuang obat-obatan dengan baik. Materi disampaikan oleh mahasiswa KKN dan sumber materi berasal dari Fakultas Farmasi UGM. Hal mendasar yang menjadi kekurangan program ini adalah bentuk follow up dari program tersebut karena tidak ada lembaga yang menjadi wadah untuk melanjutkan program.

\subsection{Pemberdayaan Berbasis Pemeriksaan Kesehatan Lansia}

Sebagian besar warga terutama lansia tidak rutin untuk memeriksakan kesehataannya. Dari data sensus kesehatan yang dilakukan, terdapat 13\% dari total jumlah warga yang 
menderita stroke. Warga yang menderita stroke sangat jarang dimonitoring keadaan kesehatannya. Dari kunjungan yang dilakukan, terdapat penderita stroke yang sudah tidak diperiksakan keadaanya selama 3 tahun. Terdapat sekitar 15\% warga yang menderita hipertensi dan juga tidak memeriksaan penyakitnya kecuali jika mengalami kekambuhan. Apabila warga mengalami gangguan kesehatan biasanya mereka memeriksakan dirinya ke bidan desa. Hanya terdapat 1 bidan desa yang mengampu kesehatan sekitar 2300-an jiwa di desa Kebonrejo. Hal ini sungguh miris. Meskipun ada fasilitas kesehatan tingkat pertama yaitu puskesmas, masyarakat desa banyak yang tidak memeriksakan diri ke puskesmas dengan alasan tidak cocok, dan tidak sedikit yang beralih untuk memeriksakan diri ke dokter swasta.

Untuk mengetahui keadaan kesehatan warga terutama lansia, program pemeriksaan kesehatan dilaksanakan. Pemeriksaan kesehatan meliputi pemeriksaan tekanan darah, gula darah, dan asam urat, serta dilakukan konseling kesehatan kepada masyarakat desa. Pemeriksaan kesehatan dilakukan sebanyak 2 kali di tempat yang berbeda. Pertama dilakukan di Dusun Nglempung di rumah kepala dusun untuk warga dusun Nglempung pada tanggal 28 Juli 2017. Sekitar 70 orang warga datang untuk memeriksakan diri. Sebagian besar adalah para lansia. Kedua, dilakukan di Balai Desa untuk warga Dusun Pruntusan dan Keboan pada tanggal 1 Agustus 2017.

Total warga desa yang melakukan pemeriksaan kesehatan mencapai \pm 150 orang. Namun apabila dilihat kembali, program pemeriksaan kesehatan ini belum dapat menjangkau kalangan lansia secara penuh. Hal ini dapat dilihat banyak lansia yang membutuhkan pelayanan, tetapi tidak dapat menempuh jarak hingga ke lokasi pemeriksaan. 
Keterbatasan fasilitas dan buruknya koordinasi dengan instansi terkait menjadi kendala tersendiri bagi program ini. Permohonan bantuan obat-obatan tidak dapat dilakukan, padahal mayoritas masyarakat Desa Kebonrejo masih drugs-oriented, selalu terpaku dan bergantung pada obat. Oleh karena itu membutuhkan edukasi terkait untuk meluruskan pola pikir warga. Hal ini dapat dilakukan dengan komunikasi yang baik dengan warga, sehingga warga dapat mengerti dan menerima sebuah paradigma kesehatan yang baru, yaitu preventif dan promotif kesehatan.

\section{KESIMPULAN DAN SARAN}

Tim mencoba untuk menyelesaikan masalah dan tantangan kesehatan kelompok lansia melalui upaya peningkatan kesehatan dengan program-program untuk kelompok rentan berupa sensus kesehatan, pelatihan kader kesehatan, pendampingan posyandu, penyuluhan swamedikasi dan pemeriksaan kesehatan lansia. Seluruh program yang direncanakan dapat berjalan secara lancar. Antusiasme dari masyarakat terhadap program kesehatan cukup baik.

Beberapa saran yang dapat menjadi perhatian baik kepada pemerintah desa maupun tim pengabdian masyarakat selanjutnya yaitu untuk memberikan perhatian khusus terhadap kelompok rentan dengan memanfaatkan kader kesehatan. Selain itu, perlu dilakukan pelatihan lanjutan yang disertai dengan pendampingan dari tenaga medis profesional. Penambahan dan perawatan sarana prasarana bagi kader kesehatan dan kegiatannya juga diperlukan untuk menunjang optimalisasi fungsi kader kesehatan di desa. Peningkatan status kesehatan masyarakat akan dapat benar-benar terwujud jika usaha-usaha yang telah diinisiasi oleh tim KKN dilanjutkan secara bekesinambungan baik oleh masyarakat maupun pemerintah desa dan daerah. 


\section{DAFTAR PUSTAKA}

Ade Setiawan. (2011). Analisis Data Eksploratif. Diakses dari http:/www.smartstat.info/blog/statistika/analisis-data-eksploratif/ diakses pada 5 Oktober 2011.

Afifa, Ireska T., Sambo, Catharine M., Medise, Bernie E. (2016). Pentingnya Memantau Pertumbuhan dan Perkembangan Anak (Bagian 1). Diakses dari http://www.idai.or.id/artikel/seputar-kesehatan-anak/pentingnya-memantaupertumbuhan-dan-perkembangan-anak-bagian-1 .

Aisah, S, Sahar, J, Hastono, S.P. (2010). Pengaruh Edukasi Kelompok Sebaya terhadap Perubahan Perilaku Pencegahan Anemia Gizi Besi pada Wanita Usia Subur di Kota Semarang [Prosiding]. Seminar Nasional Unimus, Semarang, 119-127

Anwar, F, Khomsan, A, Sukandar, D, Riyadi, H, Mudjajanto, E.S. (2010). High Participation in The Posyandu Nutrition Program Improved Children Nutritional Status, Nutrition Research and Practice 4(3), 208-214.

Ditjen Bina Gizi dan Kesehatan Ibu dan Anak Kemenkes RI. (2011). Panduan Penyelenggaraan Pemberian Makanan Tambahan Pemulihan Bagi Balita Gizi Kurang (Bantuan Operasional Kesehatan). Jakarta: Kemenkes RI.

Hoesin, Iskandar. (2004). Perlindungan terhadap Kelompok Rentan (Wanita, Anak, Minoritas, Suku Terasing, dll) dalam Perspektif Hak Asasi Manusia [Materi]. Seminar Pembangunan Hukum Nasional ke VIII Tahun 2003, Denpasar, Bali, 14 18 Juli 2003.

Kementerian Desa, Pembangunan Daerah Tertingal, dan Transmigrasi RI. (2016). Peraturan Menteri Desa, Pembangunan Daerah Tertingal, dan Transmigrasi RI 
nomor 22 tahun 2016 tentang Penetapan Prioritas Penggunaan Dana Desa Tahun 2017. Jakarta.

Negara, I.G.N.M, Gandamayu, I.B.M, Kamaryati, N.P. (2016). Ipteks Bagi Masyarakat (IbM) Kelompok Kader Posyandu Lanjut Usia (Lansia) di Desa Pererenan [Prosiding]. Seminar Nasional Hasil Penelitian dan Pengabdian kepada Masyarakat 2016: Inovasi IPTEKS Perguruan Tinggi untuk Meningkatkan Kesejahteraan Masyarakat, Denpasar: 85-90.

Pusat data dan Informasi Kementrian Kesehatan RI. (2016). Situasi Balita Pendek.

Riskesdas.(2010). Riset Kesehatan Dasar. Jakarta: Kemenkes RI.

United Nation of Children's Fund. (2012). Ringkasan Kajian Kesehatan. Diakses dari https://www.unicef.org/indonesia/id/A5_B_Ringkasan_Kajian_Kesehatan_REV.pdf.

Wijaya, I.M.K, Murti, B, Suriyasa, P. (2013). Hubungan Pengetahuan, Sikap dan Motivasi Kader Kesehatan dengan Aktivitasnya dalam Pengendalian Kasus Tuberkulosis di Kabupaten Buleleng. Jurnal Magister Kedokteran Keluarga 1(1), $38-48$.

World Health Organization. Alih bahasa oleh Heru, A. (1995). Kader Kesehatan Masyarakat. Jakarta: EGC 